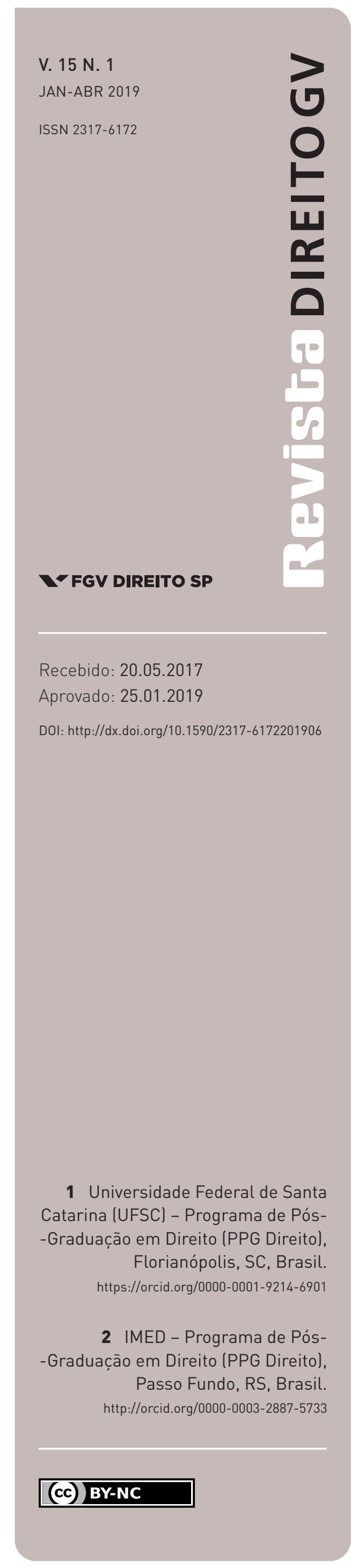

\section{Blessed be the fruit: resquícios de um viés controlista em ações sobre cirurgia de laqueadura no Judiciário de Santa Catarina (2015-2016)}

\author{
BLESSED BE THE FRUIT: INDICATIONS OF BIRTH CONTROL IN LAWSUITS ABOUT TUBAL
} LIGATION SURGERY IN THE SANTA CATARINA JUDICIARY (2015-2016)

\author{
Amanda Muniz Oliveira ${ }^{1}$ e Horácio Wanderlei Rodrigues ${ }^{2}$
}

\section{Resumo}

A cirurgia de laqueadura no Brasil é regulamentada pela Lei n. 9.263/1996, a chamada Lei do Planejamento Familiar. Esse diploma legal estabelece uma série de requisitos que, se preenchidos, garantem às mulheres o direito de se submeter a cirurgia de esterilização pelo Sistema Único de Saúde (SUS). Todavia, não são raras as reclamações sobre a ineficácia da Lei, pois mesmo quando tais critérios são preenchidos, a cirurgia não é realizada. Nesses casos, o conflito poderá chegar ao Judiciário, que decidirá sobre a contenda. 0 presente artigo se debruça sobre um caso específico: no estado de Santa Catarina, entre os anos de 2015 e 2016, houve frequentes recusas de realização de laqueadura, o que gerou a judicialização de diversos pedidos. Dessa maneira, objetivou-se identificar tanto os fundamentos utilizados por hospitais e planos de saúde para recusa da cirurgia quanto os fundamentos utilizados pelos magistrados para autorização dos procedimentos: se houve observância das exigências legais estabelecidas e se a vontade da mulher foi levada em consideração. Para tanto, foram analisadas decisões judiciais proferidas nesse tempo-espaço, a partir das quais foi possível concluir que os juízes aplicam a lei de maneira indiscriminada, ora ignorando e ora salientando os requisitos nela estabelecidos, e, ainda, que existem resquícios, talvez não intencionais, de um pensamento controlista, preocupado não em respeitar o desejo individual de cada mulher ou as normas legais estabelecidas, mas em efetivar os direitos reprodutivos a partir de uma lógica neomalthusiana: a cirurgia de laqueadura é deferida, mas não sob o fundamento de que se trata da vontade da mulher, e, sim, porque a mulher é hipossuficiente financeiramente.

\section{Palavras-chave}

Esterilização voluntária; laqueadura; planejamento familiar; direitos reprodutivos; conhecimento jurídico.

\section{Abstract}

Tubal ligation surgery in Brazil is regulated by Law n. 9.263/1996, the so-called Family Planning Law. This law establishes a series of requirements that, if completed, guarantee women the right to undergo sterilization surgery through the Unified Health System - SUS. However, complaints about the ineffectiveness of the Law are not uncommon, for even when these criteria are met, surgery is not performed. In such cases, the conflict may reach the Judiciary, which will decide on the dispute. This article focuses on a specific case: in the state of Santa Catarina, between the years 2015 and 2016, there were frequent refusals to perform a sterilization, which led to the prosecution of several requests. Thus, the objective was to identify both the arguments used by hospitals and health plans for refusing surgery and the ones used by the magistrates for authorization of the procedures: whether the legal requirements were observed 
and whether the woman's wishes were taken into account. In order to do so, we analyzed judicial judgments given in this time-space, from which it was possible to conclude that the judges apply the law indiscriminately, sometimes ignoring and sometimes stressing the requirements established in it, and also that there are remnants, perhaps not intentional, of a controlling thought, concerned not to respect the individual desire of each woman or the established legal norms, but to effect the reproductive rights from a Neo-Malthusian logic: the surgery of ligature is deferred, but not on the argument that it is about the woman's desire, but rather because the woman is financially helpless.

\section{Keywords}

Voluntary sterilization; tubal ligation; family planning; reproductive rights; legal knowledge.

\section{INTRODUÇÃO*}

Em maio de 2016, um jornal de notícias veiculava em seu portal a seguinte manchete: Hospital de Itajaí se recusa a fazer laqueadura por motivos religiosos. ${ }^{1}$ Comprovada a veracidade das informações veiculadas na reportagem, emergiu entre nós uma preocupação relativa à efetividade dos direitos sexuais e reprodutivos das mulheres brasileiras.

Como afirma Galetti (2016), vivemos no Brasil, nos anos de 2015 e 2016, o alvorecer da chamada primavera feminista. Foram perceptíveis as ocorrências de diversas ações coletivas no intuito de denunciar opressões e lutar pela efetividade de direitos destinados às mulheres, como as manifestações contra o Projeto de Lei n. 5.069/2013, de autoria do então deputado Eduardo Cunha, que restringia o atendimento às mulheres vítimas de violência sexual.

Entretanto, notícias sobre a dificuldade de efetivação dos direitos já positivados, como a vinculada pelo G1, também não eram difíceis de serem encontradas. O jornal Diário Catarinense,

* Nota dos autores: O título deste artigo faz referência ao livro O conto da aia, de Margareth Atwood. A obra narra uma distopia futurista na qual os direitos das mulheres são suprimidos por um Estado teocrático fundamentalista cristão (Gilead, que outrora se chamava Estados Unidos), sendo que, em virtude da alta taxa de esterilidade, toda mulher fértil e pecadora (conforme a teonomia cristã vigente) tem a obrigação de gerar filhos para uma elite política. Elas formam a casta das aias, cuja saudação frequente é blessed be the fruit (bendito seja o fruto), em alusão à fertilidade feminina e à coerção estatal sobre os corpos femininos.

1 Disponível em: http://osoldiario.clicrbs.com.br/sc/noticia/2016/05/hospital-de-itajai-se-recusa-a-fazerlaqueaduras-por-motivos-religiosos-5798397.html. Acesso em: 28 mar. 2017. 
por exemplo, publicou uma reportagem sobre a dificuldade de realização de aborto legal no estado de Santa Catarina $;^{2}$ mais recentemente, o caso da moradora de rua Janaína Aparecida Aquino, submetida a uma esterilização compulsória pelo Poder Judiciário, ganhou as manchetes de diversos veículos de comunicação, gerando controvérsias sobre o real consentimento da mulher em questão. ${ }^{3}$

Em meio a esse contexto de luta e denúncia, é pertinente indagar como os direitos reprodutivos das mulheres já positivados são efetivados - se é que o são, de fato. Será que as mulheres brasileiras poderiam contar com a atuação do judiciário para garantir a prática desses direitos juridicamente garantidos, em respeito à autonomia individual de suas vontades?

Sob tal perspectiva, optou-se por pesquisar o procedimento de esterilização feminina voluntária, legalmente garantido desde 1996. Tendo como ponto de partida a notícia sobre a recusa de laqueadura por motivos religiosos no estado de Santa Catarina entre 2015 e 2016, o presente artigo objetiva identificar a fundamentação dos hospitais e planos de saúde para negarem a realização da cirurgia e a justificativa dos magistrados para deferirem a realização do procedimento: se a laqueadura é judicialmente autorizada porque se trata de um desejo da mulher e está de acordo com as exigências legais ou se existem outras razões para tal deferimento. Para tanto, foram analisadas decisões judiciais proferidas no biênio referido - 2015 e 2016 - no território catarinense, a partir das quais foi possível concluir que, nesse biênio, os juízes aplicaram a lei de maneira indiscriminada, ora ignorando, ora salientando os requisitos nela estabelecidos, e que foram observados resquícios/indícios de um pensamento controlista, preocupado não em respeitar o desejo individual de cada mulher ou as normas legais estabelecidas, mas em efetivar os direitos reprodutivos a partir de um viés neomalthusiano: a cirurgia de laqueadura é deferida, mas não apenas porque a mulher a deseja e, sim, porque ela é pobre.

A perspectiva controlista refere-se à ideia de que a taxa de natalidade deve, de algum modo, ser controlada pelo Estado. Conforme Alves (2006, p. 24), o viés controlista está intimamente ligado aos demógrafos neomalthusianos, ${ }^{4}$ que vinculavam altas taxas de natalidade à pobreza:

o controle da natalidade era prioridade número um dos demógrafos neomalthusianos que viam no alto crescimento demográfico dos países pobres um entrave ao desenvolvimento econômico e, portanto, uma forma de perpetuar a pobreza. Para eles,

2 Disponível em: http://www.clicrbs.com.br/sites/swf/dc_aborto_legal/index.html\#importancia. Acesso em: 11 jun. 2018.

3 Disponível em: https://www.revistaforum.com.br/pt-divulga-nota-exigimos-punicao-pela-mutilacao-dejanaina/. Acesso em: 11 jun. 2018.

4 Para uma discussão sobre Malthusianismo e Neomalthusianismo, ver: ALVES, José Eustáquio Dinis; CORREAA, Sonia. Demografia e ideologia: trajetos históricos e os desafios do Cairo +10 . Revista Brasileira de Estudos de População, v. 20, n. 2, jul./dez. 2003. 
a alta proporção de jovens aumentava as despesas demográficas competindo com os recursos para o investimento econômico, provocando um círculo vicioso em que os pobres têm muitos filhos porque são pobres. A alta proporção de jovens dificultavam a criação da poupança necessária para, ao nível micro, conseguir a melhoria das condições de vida dos filhos e, no nível macro, obter a decolagem do desenvolvimento econômico. Para sair deste circulo vicioso, os demógrafos neomalthusianos propugnavam a adoção do controle da natalidade. Deste ponto de vista, o controle da natalidade deveria ser aplicado mesmo que de forma coercitiva.

De acordo com Alves (2006), é comum que o discurso neomalthusiano seja camuflado a partir da vontade individual do cidadão ou de políticas de planejamento familiar. Entretanto, quando se fala em controlismo, a educação e a democratização de informações sobre questões de direitos reprodutivos não estão presentes; o foco é a classe do indivíduo (não se pode ter filhos porque é pobre) e não sua autonomia (não terei filhos porque não desejo).

Nesse sentido, para demonstrar resquícios desse pensamento no judiciário de Santa Catarina entre 2015 e 2016, é preciso compreender algumas discussões relativas aos direitos reprodutivos. Inicialmente, esses direitos serão conceituados a partir dos escritos de Sônia Corrêa e Rosalind Petchesky, que levam em consideração a autonomia da mulher, e contextualizados em relação às preocupações controlistas. Na sequência, a Lei do Planejamento Familiar é apresentada a partir de seu contexto de promulgação e de seus objetivos iniciais. Por fim, a análise das decisões judiciais é realizada, levando em consideração tanto o exercício dos direitos reprodutivos como um direito humano pautado na autonomia da mulher quanto os fundamentos teleológicos da Lei do Planejamento Familiar.

\section{Direitos reprodutivos: CONCEITO e CONTEXTUalizaÇão}

A esterilização voluntária feminina, a partir da cirurgia de laqueadura, está diretamente relacionada ao exercício dos direitos reprodutivos. Decisões relativas à maternidade, como ter ou não filhos, quantidade de prole, momento de iniciar uma gravidez e realização de uma esterilização por meio de laqueadura estão amparadas na seara desses direitos. Portanto, para melhor compreender como os juízes decidem as contendas relativas à cirurgia de laqueadura, é importante entender o conceito de direitos reprodutivos, levando em consideração sua contextualização.

Segundo Corrêa e Petchesky (1996) a expressão direitos reprodutivos é recente, ganhando notoriedade a partir de 1984, no I Encontro Internacional de Saúde da Mulher, realizado na Holanda. Seu conteúdo, porém, é mais antigo: "a ideia de que as mulheres devem ser particularmente capazes de 'decidir se, quando e como querem ter seus filhos' teve origem nos movimentos feministas de controle de natalidade que se desenvolveram principalmente entre os socialistas ingleses por volta de 1830" (CORRÊA; PETCHESKY, 1996, p. 151). Dentro do 
movimento feminista, os direitos reprodutivos englobavam tanto a concepção de controle sobre o próprio corpo quanto o direito de se recusar o sexo e a própria gravidez:

Tanto a versão negativa quanto a versão afirmativa das primeiras formulações relativas aos direitos reprodutivos estavam baseadas nos princípios de igualdade, autonomia pessoal e integridade corporal. Ambas partiam de uma mesma premissa: para que as mulheres atingissem uma posição igual a dos homens na sociedade, deveriam ser respeitadas como agentes morais ativos, com projetos e objetivos próprios; elas mesmas deveriam determinar os usos - sexuais, reprodutivos ou outros - de seus corpos (e mentes). (CORRÊA; PETCHESKY, 1996, p. 152)

Nesse sentido, diversas foram as tentativas de enquadrar os direitos reprodutivos como um direito humano. Além dos movimentos de mulheres, o movimento populacional, influenciado por ideias malthuasianas, também tinha interesse nesse reconhecimento em virtude das supostas consequências sociais e econômicas oriundas do crescimento desenfreado da população.

Assim, de acordo com Corrêa, Alves e Januzzi (2006), o século XIX foi marcado pelas concepções diametralmente opostas de Condorcet e Malthus: para o primeiro, existiria uma relação positiva entre desenvolvimento e população, uma vez que as taxas de natalidade e mortalidade tenderiam a se equilibrar com o progresso socioeconômico. Já para o segundo, o desenvolvimento não passaria de uma ilusão, já que o crescimento populacional superaria os meios de subsistência:

Malthus [economista e pastor anglicano] não separava a atividade sexual da reprodução e era contra a utilização de métodos contraceptivos e o aborto, concordando apenas com que o aumento da idade para o casamento e com a abstinência sexual fora dele seriam os únicos meios aceitáveis de limitação da natalidade. (CORRÊA; ALVES; JANUZZI, 2006, p. 30)

O início do século XX, porém, foi marcado pela queda nas taxas de natalidade e mortalidade nos países desenvolvidos, fenômeno chamado pelos demógrafos de transição demográfica:

As primeiras abordagens da transição demográfica não viam contradição entre população e desenvolvimento, mas uma relação de influência mútua, já que o desenvolvimento induziria à redução das taxas de mortalidade e natalidade, e as mudanças na estrutura etária e o baixo crescimento populacional, decorrentes deste processo, ajudariam na decolagem do progresso econômico. (CORRÊA; ALVES; JANUZZI, 2006, p. 30)

De outro lado, o cenário nos países ditos subdesenvolvidos começou a ser problematizado no pós-guerra, uma vez que o equilíbrio do crescimento populacional nesses lugares ocorreu 
por fatores externos, como a importação de tecnologias e medidas sanitárias, e não internos. Em outras palavras, a estabilidade populacional não gerou uma mudança estrutural na sociedade (CORRÊA; ALVES; JANUZZI, 2006, p. 31). Como consequência, na segunda metade do século XX, os países menos desenvolvidos tendiam a apresentar elevadas taxas de crescimento demográfico:

Os dados estatísticos mostram que, de fato, as décadas de 50 e 60 do século XX foram aquelas em que o mundo apresentou o maior crescimento demográfico de toda a história da humanidade. Os demógrafos mais pessimistas tomaram estes dados como comprovação da "explosão populacional” e como justificativa para a necessidade de políticas demográficas que reduzissem a fecundidade, mesmo que de forma coercitiva. Este tipo de preocupação é que fundamenta as análises do pensamento neomalthusiano. Uma diferença fundamental entre Malthus e o neomalthusianismo é que este último aceita e receita os métodos contraceptivos como forma de limitação da fecundidade. (CORRÊA; ALVES; JANUZZI, 2006, p. 31)

Observa-se, portanto, que foi nesse contexto de debates sobre o aumento do crescimento populacional e da emergência de um pensamento neomalthusiano que a ideia de direitos reprodutivos e sexuais começa a emergir. Por essa razão, os debates não estavam direcionados a uma busca por emancipação e autonomia femininas, como desejado pelo movimento feminista, mas à efetivação de políticas de estabilização demográfica para desenvolvimento socioeconômico, ainda que para tanto fosse necessária uma intervenção coercitiva do Estado (viés controlista).

Como afirmam Corrêa, Alves e Januzzi (2006, p. 32), as Conferências Mundiais sobre População a partir dos anos 1950 (especialmente em Roma, 1954 e em Belgrado, 1965) tiveram como marco principal a polarização das posições defendidas pelos países desenvolvidos e pelos subdesenvolvidos:

De um lado, os países capitalistas avançados (Primeiro Mundo) defendiam posições neomalthusianas, argumentando que o alto crescimento populacional poderia ser um entrave ao desenvolvimento econômico. Na Conferência de Belgrado, foi feita menção explícita a métodos contraceptivos como a pílula e o dispositivo intrauterino (DIU), e à esterilização masculina e ao aborto legalizado quando aceitos pela sociedade. Os países não alinhados do Terceiro Mundo dividiram-se entre as três visões existentes: controlismo, natalismo, ou a população concebida como elemento neutro para o desenvolvimento.

Já na Conferência Mundial sobre População, ocorrida em 1974 em Bucareste, os países em desenvolvimento acusaram os países desenvolvidos de estarem assegurando sua primazia na ordem internacional por meio de controle do crescimento populacional, que estaria vinculado 
ao grau de desenvolvimento dos países como salientado pelos neomalthusianos, entusiastas de uma política de controle de natalidade para diminuição da pobreza. Por fim, acordou-se que os indivíduos deveriam ter informação e educação para exercer o direito reprodutivo (FREEDMAN; ISAACS, 1993).

A Conferência Mundial de População e Desenvolvimento (CIPD) ocorrida em 1984, no México, reafirmou esse viés populacional ao estabelecer como obrigatório aos governos a disponibilização de programas de planejamento familiar aos seus cidadãos. Segundo Corrêa, Alves e Januzzi (2006, p. 32):

[...] a posição oficial da Conferência Internacional de População do México (1984) foi pela defesa da estabilização da população mundial, no prazo mais curto possível, de maneira a permitir a melhoria do padrão de vida dos países em desenvolvimento. O Brasil foi um dos que alterou sua posição neste período, apesar de não ter adotado qualquer política explícita de controle da natalidade.

Entretanto, é preciso ter em mente que desde os anos 1970 a relação entre os direitos reprodutivos, os direitos sexuais, compreendidos como o livre exercício da sexualidade, e os direitos das mulheres havia sido evocada pelas feministas, no intuito de dissolver as fronteiras entre sexualidade e direitos humanos e disseminar a ideia de que a sexualidade ultrapassava os meros objetivos de procriação (CORRÊA; PETCHESKY, 1996).

Desse modo, a preocupação com a autonomia feminina só viria a ser formalizada em 1994, na Conferência Internacional de População e Desenvolvimento, ocorrida no Cairo. Tal fato é explicado por fatores diversos, como afirmam Corrêa, Alves e Januzzi (2006, p. 35):

O fim da Guerra Fria atenuou as disputas ideológicas e possibilitou um maior fluxo de negociações e a criação de alianças temporárias entre os diversos países presentes. Também teve destaque a forte presença de organizações não governamentais (ONGs), representando a sociedade civil. A interação entre as agendas cumulativas das diversas conferências internacionais da ONU e a presença crescente dos movimentos de mulheres, de ambientalistas e de defensores dos direitos humanos possibilitaram que o debate entre população e desenvolvimento fosse colocado em um patamar mais elevado. Por outro lado, a queda da fecundidade, que já então se constatava na maior parte do mundo em desenvolvimento, também facilitou a mudança de paradigma das políticas de controle da natalidade - que até então haviam prevalecido - para a agenda de saúde e direitos sexuais e reprodutivos.

Como salienta Mattar (2008), embora as Plataformas de Ação de Conferências Internacionais, como a CIPD, não tenham caráter vinculante para os Estados signatários, atuando mais como compromissos morais sujeitos a constrangimentos políticos, Corrêa e Petchesky (1996) 
enfatizam que é nessa ocasião que pela primeira vez os direitos reprodutivos são tratados como direitos sociais, levando em consideração o empoderamento feminino, e não a simples questão econômica (mais filhos, mais pobreza). Segundo Mattar (2008, p. 68, 69):

Tal e qual o movimento populacional, o movimento de mulheres, por sua vez, também tinha na reprodução um de seus elementos centrais. Entretanto, com outro foco: o controle da mulher sobre o seu próprio corpo, sua sexualidade e vida reprodutiva. O lema feminista da década de 70 "nosso corpo nos pertence” estava em clara oposição à interferência da Igreja e do Estado. [...]. Foi também em 1994, na Conferência sobre População e Desenvolvimento do Cairo, que o movimento feminista conseguiu deslocar definitivamente a questão demográfica para o âmbito dos direitos reprodutivos. Ficou explicitamente definido na Conferência que as políticas populacionais deveriam ser por orientadas pelos direitos humanos.

Todavia, a compreensão dos direitos reprodutivos como uma simples escolha individual a respeito da maternidade ou paternidade tem sofrido diversas críticas. Em primeiro lugar, a própria ideia de direitos humanos tem sido contestada, seja por seu caráter abstrato (capaz de conceder aos pais o mesmo direito das mães, em uma sociedade majoritariamente machista), seja por negligenciar as particularidades de gênero, raça e classe que mitigam essa suposta liberdade de escolha (ROSENFELD, 1992). Como afirmam Corrêa e Petchesky (1996, p. 156):

A desconstrução feminista da divisão público/privado aponta para um modelo de comportamento sexual e reprodutivo socialmente contextualizado, que contrasta com a suposição do modelo liberal clássico e de vários estudiosos de planejamento familiar e demografia (fazendo eco a Malthus) de que as decisões reprodutivas das mulheres refletem somente interesses pessoais estreitos. Com base em informações sociológicas e antropológicas, elas demonstram, ao contrário, que tais decisões são geralmente tomadas sob enormes pressões da família, da comunidade e da sociedade - que reforçam as normas reprodutivas vigentes - assim como compromissos internalizados para se agir de forma responsável diante dos outros.

Nesse sentido, é ingenuidade acreditar, por exemplo, que uma mulher negra de classe baixa possui o mesmo poder e liberdade de escolha que uma mulher branca de classe média, em relação ao exercício de seus direitos reprodutivos. Não é incomum que a pressão por parte de familiares, orientação religiosa, ou mesmo do próprio companheiro influencie as escolhas das mulheres, seja para conceber, seja para se abster da maternidade.

Entretanto, para evitar a armadilha de desqualificar as escolhas individuais que cada mulher faz por si mesma, mesmo sob as pressões mencionadas, Corrêa e Petchesky (1996) sugerem a 
observância de quatro princípios éticos, a serem observados pelos indivíduos e pelo Estado. Segundo as autoras:

Para que as decisões reprodutivas sejam realmente "livres" e não compelidas pelas circunstâncias ou por desespero, é necessário que existam certas condições que constituam a base dos direitos sexuais e reprodutivos, o que as feministas denominam “autonomia feminina”. Elas incluem fatores materiais e de infraestrutura, tais como transporte, creches, subsídios financeiros, bem como serviços de saúde acessíveis, humanizados e bem equipados. A simples ausência de transporte adequado pode significar um aumento da mortalidade materna e dificuldades em usar contraceptivos. Mas essas condições também incluem fatores culturais e políticos, tais como acesso à educação, renda, autoestima, e canais de tomada de decisão. Em locais onde as mulheres não têm educação, treinamento profissional ou outro papel que não o de criar filhos, a gravidez continua sendo sua melhor alternativa. (CORREAA; PETCHESKY, 1996, p. 159)

Dessa maneira, para as autoras, os direitos reprodutivos e também os direitos sexuais precisam ser compreendidos a partir de quatro princípios: (a) integridade corporal; (b) autonomia pessoal; (c) igualdade; e (d) diversidade.

A integridade corporal relaciona-se diretamente à autonomia dos indivíduos, homens e mulheres, sobre seus corpos, seja em relação à capacidade sexual e reprodutiva, seja em relação ao próprio corpo físico, condenando qualquer forma de escravidão, tortura, estupro e violência em geral. Trata-se de um direito individual, mas também de um direito social, pois sem integridade corporal os indivíduos não funcionam como membros responsáveis da comunidade (CORREAA; PETCHESKY, 1996).

A autonomia pessoal leva em consideração a escolha da mulher sobre o exercício ou não de seus direitos reprodutivos, considerando um modelo relacional e interativo que analisa as pressões externas, o aconselhamento e a disponibilidade de condições para que a escolha feminina seja tomada de modo consciente e que suas reivindicações sejam ouvidas e não negligenciadas (CORRÊA; PETCHESKY, 1996).

A igualdade refere-se tanto às relações entre homens e mulheres quanto às relações entre mulheres de diferentes estratos sociais (classe, idade, nacionalidade, cor, raça, etc.). É preciso ter em mente que a linguagem jurídica neutra pode vir a conceder as mesmas prerrogativas para homens e mulheres, ignorando todo um sistema histórico de submissão feminina. Por exemplo, ao se determinar que os casais devem escolher o número de filhos, é preciso ter em mente que a gravidez ocorrerá no corpo feminino e que em algumas situações a mulher poderá ser coagida a engravidar contra sua vontade, atendendo a anseios exclusivamente masculinos/paternos, familiares ou religiosos. Além disso, é preciso garantir as mesmas condições de escolha para os diversos tipos de mulheres presentes na sociedade; "os problemas de 
discriminação surgem quando métodos seguros tais como camisinhas ou diafragmas, pílulas com baixas doses de hormônio ou condições de aborto seguro estão disponíveis apenas para mulheres com recursos financeiros" (CORREAA; PETCHESKY, 1996, p. 167).

A diversidade, por sua vez, salienta a necessidade de se respeitarem as diferenças culturais, religiosas, sexuais, etc. entre os indivíduos, afastando a linguagem universalizante do direito. Ao contrário do que possa parecer, o respeito à diversidade não é absoluto, mas deve ser evocado sempre que a diferença promover o desenvolvimento das mulheres e respeitar sua autodeterminação (CORRÊA; PETCHESKY, 1996).

Dessa maneira, mais do que a simples possibilidade de escolha individual a respeito da maternidade, os direitos reprodutivos passaram a englobar, ainda, as preocupações relativas às condições sociais, econômicas e políticas que tornavam tais decisões possíveis (CORREA; PETCHESKY, 1996). Voltaremos a abordar tais questões em seção posterior do presente artigo, quando será realizada a análise das decisões judiciais sobre a autorização de cirurgia de laqueadura. Na ocasião, argumentaremos que a preocupação com a autonomia feminina parece não ter adentrado os espaços jurídicos, que ainda reproduzem pensamentos controlistas, autorizando a cirurgia não por ser vontade da mulher, mas pelos impactos socioeconômicos que a gravidez de determinados sujeitos traria.

Vejamos, agora, o contexto de promulgação da Lei do Planejamento Familiar no ordenamento jurídico brasileiro, o principal instrumento direcionado à efetivação dos direitos reprodutivos. Veremos também a teleologia de seus dispositivos normativos, frequentemente criticados e inobservados seja por profissionais da saúde, seja pelo próprio judiciário.

\section{As preocupações da Lei do Planejamento Familiar}

Em $1^{\circ}$ de abril de 1992, foi instaurada no Brasil uma Comissão Parlamentar Mista de Inquérito (CPMI), a pedido da deputada Benedita da Silva, com o objetivo principal de se averiguar as razões para o aumento de cirurgias de laqueadura em mulheres brasileiras (BRASIL, 1993).

Para tanto, o relatório final da CPMI utilizou a pesquisa realizada por Délcio da Fonseca Sobrinho, no intuito de situar historicamente as posições do Brasil sobre o planejamento familiar. O país teria passado por três fases bem delimitadas, sendo a primeira delas identificada como um período pró-natalista, iniciado nos primórdios da Independência até 1964, cujo objetivo principal seria a melhoria da raça brasileira (BRASIL, 1993). Um dos exemplos desse pensamento está presente em Decreto-Lei de 1945, publicado durante o governo de Getúlio Vargas, que, em seu art. $2^{\circ}$ elencava:

Art. $2^{\circ}$ Atender-se-á, na admissão dos imigrantes, à necessidade de preservar e desenvolver, na composição étnica da população, as características mais convenientes da sua ascendência europeia, assim como a defesa do trabalhador nacional. (BRASIL, 1945, grifo nosso) 
A partir de 1964 as polêmicas sobre controle populacional e desenvolvimento social começam a chegar ao Brasil, ganhando notoriedade a partir de 1965, quando organizações de financiamento de projetos controlistas, como a International Planned Parenthood Federation (IPPF), se instalam no país. Essas organizações acreditavam que países subdesenvolvidos deveriam ter taxas de natalidade menores, assim como as camadas menos favorecidas desses países precisavam ter a natalidade controlada, para evitar a pobreza. A IPPF irá apoiar a criação da Sociedade de Bem-Estar Familiar no Brasil (BEMFAM), composta por obstetras da Universidade Federal do Rio de Janeiro (UFRJ). Esse segundo momento foi marcado por uma polarização entre os controlistas, que vinculavam as altas taxas de natalidade a um baixo desenvolvimento econômico e social, e o governo militar, que adotava um viés natalista em razão da segurança nacional (mais sujeitos, mais soldados) (BRASIL, 1993).

A partir dos anos 1970, parte dos militares passa a defender a ideia de uma convulsão social, causada pelo crescimento da população, sob influência da Escola Superior de Guerra (ESG), e a Igreja Católica passa a permitir métodos naturais de anticoncepção. Desse modo, organizações como a BEMFAM e o Centro de Pesquisa e Assistência Integrada à Mulher e à Criança (CPAIMC) passam a adotar um discurso voltado à prática do planejamento familiar, que, influenciado por um viés controlista, irá contribuir para a disseminação de uma cultura da laqueadura, causando um aumento massivo no número de mulheres esterilizadas: a laqueadura era vista como um caminho natural após a concepção de um ou dois filhos, e informações sobre outros métodos anticonceptivos reversíveis e menos invasivos não eram disseminadas (BRASIL, 1993).

Ao final da CPMI, restou comprovado que havia um "claro interesse internacional na implementação de controle demográfico” (BRASIL, 1993, p. 116) no país, além de restar

[...] confirmada a esterilização em massa de mulheres no Brasil [...]. O contexto em que as esterilizações são realizadas é bastante perverso: ausência de outras alternativas contraceptivas disponíveis e reversíveis e desinformação quanto aos riscos, sequelas e irreversibilidade da laqueadura.

Em percentual significativo, as esterilizações são realizadas durante o curso de cesarianas, indicadas com o objetivo de se realizar, simultaneamente, a laqueadura tubária. Essa situação contribui para que o Brasil sustente internacionalmente o lastimável título de campeão da prática de cesarianas.

É especialmente preocupante a alta taxa de arrependimento pós-laqueadura tubária (esterilização cirúrgica), o que comprova não estarem as mulheres dispondo de tempo nem informações suficientes para amadurecimento da decisão.

A maior incidência de esterilização em mulheres de raça negra foi denunciada pelo movimento negro, como um aspecto do racismo praticado no Brasil. Os dados levantados pelo IBGE [...] não confirmam a denúncia, mas é fato notório a dificuldade de se apurar com precisão a informação relativa à cor da pele dos brasileiros. (BRASIL, 1993, p. 117) 
Além disso, como não havia lei disciplinando a realização de cirurgia de laqueaduras, grande parte dos procedimentos era realizado de maneira clandestina, por medo de sanções criminais e por questões financeiras, já que o dinheiro gasto nesses procedimentos não era ressarcido ao hospital pelo Estado. Também se averiguou ser comum a troca de votos pela cirurgia e a recusa por parte de empregadores em contratar mulheres não esterilizadas. Como forma de modificar esse desastroso quadro, foi recomendado ao Poder Legislativo a discussão e votação do Projeto de Lei n. 3.633/1993, que tratava das políticas de planejamento familiar (BRASIL, 1993).

O projeto foi apensado a outras seis propostas, já em trâmite, e após anos de debates e modificações foi promulgado como a Lei n. 9.263/1996, a conhecida Lei do Planejamento Familiar. De acordo com essa lei, o planejamento familiar é um direito, compreendido como a livre decisão a respeito da maternidade ou paternidade, e não pode ser utilizado para fins de controle demográfico (BRASIL, 1996).

O referido diploma legal, em seu art. 10, estabelece dois casos nos quais a esterilização voluntária é possível: (a) por vontade livre de indivíduos civilmente capazes, maiores de 25 anos ou com dois filhos vivos; e (b) nos casos em que há risco à saúde ou à vida da mulher ou do futuro embrião. No primeiro caso, é preciso que haja a decorrência de 60 dias entre a manifestação da vontade e a efetivação da cirurgia; no segundo, é preciso que haja laudo assinado por dois médicos (BRASIL, 1996).

O prazo de 60 dias exigido pela lei entre a expressão do desejo e a ocorrência do procedimento é explicado a partir do arrependimento vislumbrado nas mulheres brasileiras submetidas à laqueadura imediata. Ademais, a lei também exige (art. 10, $\S 1^{\circ}$ ) que o indivíduo assine um termo de livre consentimento, no qual afirma ter ciência dos riscos cirúrgicos, dos efeitos colaterais, de seu caráter irreversível e da existência de outros métodos contraceptivos passíveis de reversão (BRASIL, 1996). Sobre o tema, escreve o senador Lúcio Alcântara, relator do parecer da Comissão de Assuntos Sociais, ao avaliar o projeto de lei:

A exigência de manifestação expressa da vontade por parte da pessoa [...] com antecedência mínima de sessenta dias em relação a data do ato cirúrgico, a exigência de aconselhamento prévio e a permissão de oferta deste método apenas por instituições que oferecerem todas as demais opções de meios e métodos de contracepção visa impedir seu uso abusivo como se viu ocorrer no país nos últimos anos. [...]. [Ademais], estudos também evidenciam que a maior proporção de arrependimentos está associada ao desconhecimento ou à não disponibilidade de métodos alternativos não definitivos e o desconhecimento dos riscos e consequências do método cirúrgico, em especial de sua irreversibilidade. (BRASIL, 1995, p. 94-95)

Nem sempre, porém, tais critérios são observados, seja para negar a realização da laqueadura (CAETANO, 2014), seja para deferi-la, como abordaremos no tópico específico. 
Como consequência do alto índice de cesarianas efetivadas para ocultar as laqueaduras, outrora ilegais e não reembolsáveis pelo SUS (CAETANO, 2014), a lei proibiu sua realização logo após o parto (art. 10, $\S 3^{\circ}$ ), sendo necessário aguardar um período de 42 dias após o nascimento da criança para que a mãe seja submetida a cirurgia de esterilização, justamente para diminuir o número de cesáreas (BRASIL, 1999). Sobre o assunto, escreve Alcântara:

É de conhecimento público - denunciada e comprovada pela Comissão Parlamentar Mista de Inquérito destinada a examinar a incidência de esterilização em massa de mulheres no Brasil, que apresentou seu relatório em 1993, pela literatura médica nacional e pela imprensa leiga - a prática de realizar parto cesáreo para acobertar a ligação das trompas. Esta prática, que tem graves consequências para a saúde da mulher e do concepto, deve ser coibida em nosso meio. [...] A indicação inescrupulosa, e muitas vezes criminosa, de realizar um parto cesáreo ao invés de um parto normal é ou foi - como já se discutiu frequente em nosso País, não cabendo outra alternativa que desestimulá-la e penalizá-la de todas as formas. (BRASIL, 1995, p. 80-81)

Esse requisito tem sido ignorado tanto por profissionais da saúde (CAETANO, 2014) quanto pelos próprios magistrados nos casos em que se faz necessário judicializar a questão, conforme será demonstrado posteriormente.

Um dispositivo bastante questionado refere-se à necessidade de autorização do cônjuge para realização do procedimento (art. 10, § 5º), independentemente do sexo (BRASIL, 1996). Segundo as discussões do projeto de lei, o dispositivo foi pensado no intuito de evitar que o casal caísse em um "individualismo egoísta do cada um por si" (BRASIL, 1995, p. 95). O dispositivo é objeto de duas Ações Diretas de Inconstitucionalidade (ADI), que tramitam no Supremo Tribunal Federal (ADI 5911 e ADI 5097), ${ }^{\mathbf{5}}$ sendo afastado em uma das decisões judiciais analisadas, conforme será demonstrado no próximo tópico.

Apesar da promulgação da Lei do Planejamento Familiar e de sua preocupação com todas as questões elencadas, diversas pesquisas constatam que os resultados esperados não foram ainda obtidos. Conforme Caetano (2014, p. 314), uma pesquisa realizada em 1999 no intuito de avaliar os efeitos da Lei do Planejamento Familiar na Região Metropolitana de São Paulo concluiu "que os médicos eram pouco aderentes à legislação, utilizando critérios próprios, definidos caso a caso". Nesse mesmo sentido, Carvalho et al. (2007, p. 2912), em pesquisa sobre o tema na Região Metropolitana de Campinas, afirmam:

5 Mais informações em: http://www.stf.jus.br/portal/cms/verNoticiaDetalhe.asp?idConteudo=375595. Acesso em: 13 jun. 2018. 
Todos os respondentes em cujos municípios se realizava a esterilização cirúrgica declararam existir critérios de idade e número de filhos para atender as solicitações. Quatro deles referiram que esses critérios foram estabelecidos com base na regulamentação legal (Lei $\left.n^{\circ} .9 .263\right)$. Porém, quando os entrevistados explicitaram esses critérios, observou-se que, em dois desses municípios, os critérios de idade e número de filhos não eram exatamente aqueles que constam da lei. Em um deles, por exemplo, a idade para autorizar a laqueadura dependia do número de filhos, de acordo com o hospital em que a cirurgia seria realizada: 25 anos-dois filhos ou 28 anos-três filhos ou 30 anos-dois filhos. Em geral, os coordenadores relataram variações em torno desses critérios de idade e número de filhos e a adição de outros aspectos: que o último filho vivo deva ter no mínimo um ano de idade; que a pessoa esteja há pelo menos cinco anos em união estável; que resida no município há dois anos no mínimo; que as mulheres tenham feito citologia oncótica há seis meses no máximo. (Grifo nosso)

Não é incomum, portanto, que profissionais da saúde ignorem os critérios estabelecidos em lei e dificultem a realização da laqueadura. Para Osis et al. (2009, p. 632), "a tendência dos profissionais entrevistados foi considerar que [esses critérios] contribuem para o arrependimento pós-esterilização, pois permitem que as cirurgias sejam realizadas em pessoas bem jovens e com poucos filhos", o que explicaria essa resistência.

A lei também é mitigada nos casos em que os juízes deferem a realização da laqueadura, ao argumento de que a mulher solicitante é financeiramente hipossuficiente e, ainda que não preencha os requisitos legais, deve fazer a cirurgia. Tal fato aponta para a existência de indícios, ainda que inconscientes, da manutenção de um pensamento controlista, que não se pauta pela autonomia da vontade da mulher, mas, sim, pelos impactos socioeconômicos que sua gravidez terá. No próximo tópico apresentaremos nossa análise sobre o assunto.

\section{INDÍCIOS DE UM PENSAMENTO CONTROLISTA EM DECISÕES JUDICIAIS SOBRE laqueadura em Santa Catarina}

No intuito de encontrar respostas para nossas indagações surgidas com notícia intitulada Hospital de Itajaí se recusa a fazer laqueadura por motivos religiosos, decidimos analisar decisões judiciais proferidas no estado de Santa Catarina entre os anos de 2015 e 2016 - período temporal próximo ao da notícia veiculada. ${ }^{6}$

6 A notícia foi veiculada em maio de 2016, conforme o link: http://osoldiario.clicrbs.com.br/sc/noticia/2016/05/hospital-de-itajai-se-recusa-a-fazer-laqueaduras-por-motivos-religiosos-5798397.html. Acesso em: 28 mar. 2017. 
Para tanto, iniciamos uma busca no site do Tribunal de Justiça de Santa Catarina, em 6 de março de 2017. Primeiro foram buscadas no Diário da Justiça Eletrônico ${ }^{7}$ as seguintes palavras-chave: Lei n. 9.263 de 1996 (nenhum resultado); planejamento familiar (18 resultados); esterilização voluntária (nenhum resultado); laqueadura (49 resultados) e Lei n. 9.263/ 1996 (3 resultados).

Em seguida, fizemos busca na sessão de consulta de jurisprudência do site ${ }^{\mathbf{8}}$ com os mesmos termos: Lei n. 9.263 de 1996 (nenhum resultado); planejamento familiar (70 resultados); esterilização voluntária (4 resultados); laqueadura (53 resultados); e Lei n. 9.263 de 1996 (7 resultados).

No total, encontramos 204 decisões judiciais, dentre sentenças, agravos, recursos e decisões interlocutórias. Após leitura de cada uma dessas decisões, restringimos esse número para o total de 62 decisões relativas, de forma direta ou indireta, a casos nos quais gestantes necessitaram buscar o Judiciário para realizar cirurgia de laqueadura. Algumas configuram decisões repetidas em razão de a busca ter sido feita por palavras-chave e, por vezes, uma mesma decisão apresentar mais de uma palavra usada; outras se referiam a pessoas incapazes solicitando a realização do procedimento por meio de seus tutores. ${ }^{9}$ Também observamos que diversas decisões eram relativas a um mesmo caso e, por isso, as organizamos por processo. Adotada essa opção, chegamos ao total de 20 (vinte) $\operatorname{casos}^{10}$ relativos a pedidos para

7 Para tanto, selecionamos a opção buscar frases exatas e indicamos o seguinte período temporal: $01 / 01 / 2015$ a 31 / 12 / 2016. Link para a busca via Diário da Justiça Eletrônico: http: / /busca.tjsc.jus.br/dje-consulta/. Acesso em: 28 mar. 2017.

8 Para tanto, selecionamos as seguintes opções: inteiro teor; Acórdãos do Tribunal de Justiça; Acórdãos do Conselho da Magistratura; Acórdãos das Turmas Recursais e de Uniformização; Despachos das Vice-Presidências; Decisões Monocráticas do Tribunal de Justiça; Acórdãos das Turmas Recursais e de Uniformização; Decisões Monocráticas das Turmas Recursais; com a expressão; Órgão julgador: todos. Indicamos o seguinte período temporal: $01 / 01 / 2015$ a $31 / 01 / 2016$.

9 Este tema também apresentou detalhes que chamaram nossa atenção, embora não seja abordado na presente pesquisa. Tem-se por exemplo o Mandado de Segurança n. 2014.068404-3, de Araranguá, cuja causa de pedir é a negativa de cirurgia de laqueadura a uma mulher bipolar; o argumento seria sua incapacidade civil.

10 Os 20 processos encontrados foram os seguintes: Apelação Cível n. 2014.054880-2, de Navegantes; Processo n. 033.09.032353-2, de Itajaí; Processo n. 0307599-13.2016.8.24.0033, de Itajaí; Reexame Necessário n. 2015.083062-9, de Correia Pinto; Processo n. 033.12.010197-4, de Itajaí; Processo n. 030076746.2016.8.24.0135, de Navegantes; Processo n. 0304476-75.2014.8.24.0033, de Itajaí; Processo n. 0301858-78.2015.8.24.0048, de Balneário Piçarras; Processo n. 0000899-50.2014.8.24.0135, de Navegantes; Processo n. 135.12.001999-3, de Navegantes; Processo n. 0006188-32.2012.8.24.0135, de Navegantes; Processo n. 0301871-77.2015.8.24.0048, de Balneário Piçarras; Processo n. 033.11.004061-1, de Itajaí; Processo n. 0018018-10.2012.8.24.0033, de Itajaí; Processo n. 0303664-33.2014.8.24.0033, de Itajaí; Apelação Cível n. 2014.025298-7, de Balneário Piçarras; Processo n. 0007969-41.2011.8.24.0033, de 
realização de laqueadura, com decisões proferidas entre 2015 e 2016, ${ }^{11}$ sendo 18 (dezoito) deles em relação a cirurgia pelo SUS e 2 (duas) por planos de saúde da rede privada. No intuito de tornar o trabalho mais abrangente, procuramos ler e nos informar a respeito de todo o andamento processual desses 20 casos; entretanto, em observância ao recorte temporal delimitado, teremos por foco as decisões emitidas no referido período de tempo. Indicaremos quando decisões de outras datas forem utilizadas. Desses 20 casos analisados, 19 tiveram o provimento favorável à autora (mulher) e apenas 1 desfavorável.

Dessa maneira, a partir da análise das decisões proferidas nos casos delimitados, também se analisaram os motivos da recusa de hospitais e planos de saúde em realizar a laqueadura nas mulheres protagonistas das ações e, posteriormente, os fundamentos pelos quais os magistrados deferiam a realização do procedimento. Em um primeiro momento, acreditávamos haver uma explicação não convincente do ponto de vista jurídico por parte dos hospitais e planos de saúde para que elas não fossem submetidas à cirurgia de esterilização voluntária, por exemplo, questões morais ou religiosas. Todavia, verifica-se que a negativa na grande maioria das ações foi pautada na lei, que veda a realização da cirurgia durante os períodos de parto, no intuito de desincentivar as cesarianas, como explicado no tópico anterior.

Das 20 mulheres que recorreram ao judiciário, restou claro a partir das decisões analisadas que pelo menos $14^{12}$ demandavam a realização de cirurgia de laqueadura durante o parto, conflitando, assim, com a vedação legal. É o caso, por exemplo, do pedido de uma mulher avaliado pelo desembargador Edemar Gruber:

[...] sua pretensão esbarrou na vedação constante do $\S 2^{\circ}$ do mesmo dispositivo, uma vez que pretendia realizar a esterilização durante o período de parto, sem restar comprovada a necessidade por cesarianas sucessivas anteriores. A proibição, no entanto, ainda poderia ser superada caso houvesse relatório assinado por 2 (dois) médicos atestando risco à [sua] saúde em caso de novo procedimento cirúrgico, circunstância que, do mesmo modo, não se registra nos autos. (Voto em Apelação Cível n. 2014.054880-2, de Navegantes)

E mesmo nos casos em que a mulher alega possuir algum problema de saúde, existe a negação por parte dos hospitais, sob diversos argumentos: a necessidade de laudo assinado

Itajaí; Processo n. 0029503-89.2012.8.24.0038, de Joinville; Processo n. 306880-31.2016.8.24.0033, de Itajaí; Apelação Cível n. 2014.024864-1, de Itajaí.

11 Saliente-se, decisões proferidas. Algumas ações haviam sido ajuizadas anos antes e outras ainda não haviam sido concluídas quando da escrita do artigo.

12 Nos outros processos não foi possível identificar o motivo da recusa, pois não tivemos acesso aos autos completos. 
por dois médicos, em observância à Lei do Planejamento Familiar ${ }^{13}$ (como na citação anterior); a exigência de uma ordem judicial; e ainda a suposta necessidade de um prazo de 60 dias entre o parto e a laqueadura:

[...] a interessada [...] é portadora de hipertensão grave, estando grávida de vinte e uma semanas, já tendo realizado duas cesarianas previamente. Diante disso, deseja realizar o procedimento de laqueadura para planejamento familiar e resguardar sua saúde, no entanto, o Hospital Nossa Senhora dos Navegantes afirma que para que o procedimento seja realizado durante uma cesariana é necessário ordem judicial. (Sentença em Ação Civil Pública n. 0000899-50.2014.8.24.0135, Navegantes, grifo nosso)

\section{[...] o pedido foi negado à requerente, sob o argumento que o procedimento de laqueadura tubária} somente poderia ser realizado 60 (sessenta) dias após o parto e não durante o mesmo, configurando a omissão estatal, o que legitima o ajuizamento da presente demanda. (Voto em Apelação Cível n. 2014.043265-7, de Navegantes, grifo nosso)

Sobre esse último ponto, não encontramos menção legal a esse intervalo; na verdade, os 60 dias a que a lei se refere são aqueles entre a manifestação da vontade e a efetiva cirurgia. ${ }^{14}$ Em trabalhos acadêmicos encontramos menção a um prazo de 42 dias, conforme a Portaria n. 48/1999, do Ministério da Saúde, ${ }^{15}$ no intuito de desestimular a realização de

13 Lei n. 9.263/96: "Art. 10. Somente é permitida a esterilização voluntária nas seguintes situações: II risco à vida ou à saúde da mulher ou do futuro concepto, testemunhado em relatório escrito e assinado por dois médicos”.

14 Lei n. 9.263/96: “Art. 10. Somente é permitida a esterilização voluntária nas seguintes situações: I em homens e mulheres com capacidade civil plena e maiores de vinte e cinco anos de idade ou, pelo menos, com dois filhos vivos, desde que observado o prazo mínimo de sessenta dias entre a manifestação da vontade e o ato cirúrgico, período no qual será propiciado à pessoa interessada acesso a serviço de regulação da fecundidade, incluindo aconselhamento por equipe multidisciplinar, visando desencorajar a esterilização precoce” (grifo nosso).

15 Portaria n. 48/1999, do Ministério da Saúde: "Art. 4 - De acordo com o disposto no Artigo 10 da Lei 9.263 , de 12 de janeiro de 1996, que regula o parágrafo $7^{\circ}$ da Constituição Federal, que trata do planejamento familiar, estabelece penalidades e dá outras providências: somente é permitida a esterilização voluntária sob as seguintes condições: [...] Parágrafo único. É vedada a esterilização cirúrgica em mulher durante períodos de parto, aborto ou até o $42^{\circ}$ dia do pós-parto ou aborto, exceto nos casos de comprovada necessidade, por cesarianas sucessivas anteriores, ou quando a mulher for portadora de doença de base e a exposição a segundo ato cirúrgico ou anestésico representar maior risco para sua saúde. Neste caso, a indicação deverá ser testemunhada em relatório escrito e assinado por dois médicos". 
partos cesáreos desnecessários, como já comentado. As recusas dos hospitais, portanto, são pautadas em motivações diversas, o que aponta para uma perigosa arbitrariedade.

Ainda no que se refere aos motivos da recusa por parte dos hospitais, um caso específico merece maior atenção. Segundo o hospital que se negou a realizar o procedimento, a requerente também não cumpria todos os requisitos legais (ausente laudo assinado por dois médicos, conforme art. 10, inc. II), mas de acordo com a juíza havia fortes indícios da necessidade da realização da laqueadura, pois a autora já havia sofrido sete abortos. A recusa veio, segundo a juíza, motivada pela alegação principal de que o hospital não possuía credenciamento com o SUS e demais convênios particulares para realização da cirurgia por questões religiosas:

Na situação em tela, portanto, verifica-se que a justificativa apresentada pelo hospital requerido, no sentido de que por tratar-se de entidade religiosa não aderiu ao credenciamento da laqueadura (fls. 134-135), não pode se sobrepor a um direito constitucional assegurado à autora, a qual manifestou expressamente e de forma inequívoca a vontade de realizar a esterilização não sendo razoável submetê-la a novo procedimento cirúrgico para tal fim, haja vista os riscos daí decorrentes. (Sentença em Processo n. 0007969-41.2011.8.24.0033, Itajaí, grifo nosso)

Essa ação foi ajuizada na comarca de Itajaí (SC), tendo por réu o Hospital e Maternidade Marieta Konder Bornhausen. Esse hospital aparece como réu em 11 dos 20 casos analisados, o que despertou nossa atenção. O hospital é administrado pelo Instituto das Pequenas Missionárias de Maria Imaculada, ${ }^{16}$ uma obra filantrópica de freiras católicas, e em outro caso analisado, o juiz também afirma que a negativa foi feita por motivos religiosos:

Na situação em tela, verifica-se que a exigência burocrática não deve se sobrepor a um direito constitucional assegurado à requerente, tampouco a justificativa do hospital requerido, que por se tratar de entidade religiosa não aderiu ao credenciamento da laqueadura. ${ }^{17}$ (Sentença em Processo n. 033.12.010197-4, Itajaí, grifo nosso)

Para compreender então o suposto embasamento religioso da recusa, consultamos uma série de documentos eclesiásticos, ${ }^{18}$ que podem ser resumidos pela transcrição do Catecismo

16 Conforme reportagem disponível no link: https://ricmais.com.br/sc/programas/rictv-itajai/hospitalde-itajai-se-nega-a-fazer-laqueadura-e-vasectomia-por-questoes-religiosas. Acesso em: 28 mar. 2017.

17 Trata-se de trecho de decisão emitida em 2013 nos autos do processo n. 033.12.010197-4. Trouxemos a decisão aos autos no intuito de demonstrar a informação localizada, ainda que fora do período temporal delimitado.

18 Os documentos consultados foram: PIO XII, Alocução ao Congresso da União Católica Italiana das Parteiras, 29 de outubro de 1951, em AAS 43 (1951), p. 835-854; SAGRADA CONGREGAÇÃO PARA A DOUTRINA DA 
da Igreja Católica, item 2297: 19 “A não ser por indicações médicas de ordem estritamente terapêutica, as amputações, mutilações ou esterilizações directamente voluntárias de pessoas inocentes, são contrárias à lei moral”. Isso explicaria a recusa por parte da instituição.

Em algumas decisões, o hospital justifica suas razões para a recusa com base no seu não credenciamento junto ao SUS:

Às págs. 59/66, apresentou contestação levantando o seguinte: não possuir habilitação junto ao Ministério da Saúde que possibilite realizar o procedimento. (Processo n. 0301858 -78.2015.8.24.0048, Balneário Piçarras, grifo nosso)

Aduz o agravante que, por não se encontrar habilitado junto ao Ministério da Saúde para a realização do procedimento solicitado, este teria que ser realizado no Hospital Nossa Senhora da Penha, localizado no Município do mesmo nome. (Voto em Agravo de Instrumento n. 0156766-19.2015.8.24.0000, Balneário Piçarras, grifo nosso)

Conforme Portaria n. 48/1999 do Ministério da Saúde, art. 50 ${ }^{20}$ o credenciamento é feito pelos gestores municipais e estaduais. Contudo, para tanto, os hospitais devem preencher alguns requisitos, por exemplo, oferecer todas as opções de meios e métodos contraceptivos reversíveis. Parece-nos, assim, que o fundo religioso permanece quanto a esse credenciamento, pois o hospital não demonstra interesse em cumprir esses requisitos, justamente por sua orientação religiosa. E, desse modo, caso realizasse o procedimento de laqueadura, estaria agindo na ilegalidade - pois não autorizado.

FÉ, Resposta sobre a esterilização nos hospitais católicos, Quaecumque sterilizatio. AAS 68 (1976). 13 de março de 1975; CATECISMO DA IGREJA CATÓLICA, itens 2297 e 2399; PAULO VI, Carta Encíclica Humanae Vitae, sobre a regulação da natalidade. n. 14; PIO XII, Alocução aos Participantes do Congresso de Associação Italiana de Urologia, de 8 de outubro de 1953.

"O Catecismo é uma exposição da fé da Igreja e da Doutrina Católica, testemunhadas ou iluminadas pela Sagrada Escritura, pela tradição apostólica e pelo Magistério da Igreja. O Catecismo é, sobretudo, um instrumento válido e legítimo da comunhão eclesial e serve como uma norma segura para o ensino da fé, do qual todos os batizados são convocados a transmitir às novas gerações." Disponível em: http:// formacao.cancaonova.com/liturgia/catequese-liturgica/o-que-e-o-catecismo-da-igreja-catolica/. Acesso em: 28 mar. 2017.

Portaria n. 48/1999, do Ministério da Saúde: “Art. $5^{\circ}$ - Cabe aos gestores estaduais e municipais de saúde, em condição de Gestão Plena do Sistema Municipal (NOB-96), procederem ao credenciamento das unidades de saúde para a realização dos procedimentos de Cesariana com Laqueadura Tubária em Pacientes com Cesarianas Sucessivas Anteriores/Risco de Vida, Laqueadura Tubária e Vasectomia, conforme modelo em anexo. Parágrafo único. No âmbito do Sistema Único de Saúde somente poderão realizar esterilização cirúrgica as instituições que atenderem aos seguintes critérios: I - estar autorizada pelo gestor estadual ou municipal; II - oferecer todas as opções de meios e métodos contraceptivos reversíveis, e III - comprovar a existência de médico capacitado para realização do ato”. 
De fato, alguns magistrados entendem ser impossível que o hospital faça o procedimento sem estar devidamente cadastrado:

O segundo requerido em sede de contestação suscitou a impossibilidade no fornecimento do procedimento pleiteado, por não possuir habilitação junto ao Ministério da Saúde. Tenho que o dito impedimento encontra-se plenamente justificável, uma vez que para realização de procedimento de esterilização, necessário se faz que o nosocômio esteja regularmente habilitado junto ao Ministério da Saúde. Portanto, não sendo o segundo requerido capaz de realizar o procedimento cirúrgico em apreço, não possui legitimidade para integrar a presente lide. Logo, determino a exclusão do Hospital e Maternidade Marieta Konder Bornhausen do polo passivo da presente demanda. (Sentença em Processo n. 0301858-78.2015.8.24.0048, Balneário Piçarras)

De fato, a agravante não conta com habilitação administrativa emitida pelo Ministério da Saúde que lhe credencie a fornecer o serviço médico de esterilização voluntária através do Sistema Único de Saúde - SUS. [...]. Desse modo, claro está, pelas razões explicitadas, que ao agravante não poderia ser imputada a obrigação de realizar o indigitado procedimento cirúrgico, como, aliás, restou reconhecido pelo próprio Juízo singular, afinal de contas, segundo vetusto aforismo, "ninguém pode ser obrigado ao impossível". (Voto em Agravo de Instrumento n. 0156766-19.2015.8.24.0000, Balneário Piçarras, grifo nosso)

Todavia, é possível lançar uma base argumentativa a partir da hierarquia de leis no Brasil. Conforme José Cretella Júnior (1974, p. 450), a Portaria (classificação do documento que exige o credenciamento de hospitais para realização de laqueadura) é um ato administrativo, de natureza infralegal, cujo objetivo seria o de efetivar os dispositivos genéricos contidos na lei. Nesse ponto, diz Cretella Júnior (1974, p. 456), “ato administrativo em oposição à lei não vale”. Acompanhando esse raciocínio, encontramos decisões judiciais que determinavam a efetivação da cirurgia pelo Hospital e Maternidade Marieta Konder Bornhausen:

Na situação em tela, verifica-se que a exigência burocrática não deve se sobrepor a um direito constitucional assegurado à requerente, tampouco a justificativa do hospital requerido, que por se tratar de entidade religiosa não aderiu ao credenciamento da laqueadura. [...]. Por essas razões, o pleito inicial merece ser julgado procedente, confirmando-se a tutela antecipatória concedida, condenando-se o requerido a arcar com todos os custos decorrentes do respectivo procedimento cirúrgico. (Sentença em Processo n. 033.12.010197-4, Itajaí, grifo nosso)

Na situação em tela, portanto, verifica-se que a justificativa apresentada pelo hospital requerido, no sentido de que por tratar-se de entidade religiosa não aderiu ao credenciamento 
da laqueadura (fls. 134-135), não pode se sobrepor a um direito constitucional assegurado à autora [...]. Por essas razões, o pleito inicial merece ser julgado procedente, confirmando-se a tutela antecipatória concedida e os pedidos pleiteados na inicial. (Sentença em Processo n. 0007969-41.2011.8.24.0033, Itajaí, grifo nosso)

Observe-se ainda que nos fragmentos acima existem menções a antecipações de tutela para que o hospital realizasse as laqueaduras antes do fim do processo. De fato, encontramos referências a essas ordens em algumas decisões judiciais, mas todas apontando para a sua não realização:

A autora informou na petição retro que o Hospital e Maternidade Marieta Konder Bornhausen está se recusando ao cumprimento do comando judicial deferido liminarmente nos presentes autos (realização de laqueadura), em que pese as rés já tenham se comprometido a realizar o procedimento. Requereu, em aditamento à inicial, a inclusão do hospital mencionado no polo passivo da demanda. ${ }^{21}$ (Despacho em Processo n. 0307599-13.2016.8.24.0033, Itajaí)

A tutela antecipatória foi deferida, determinando-se que a parte ré adotasse as medidas cabíveis para a esterilização por ocasião da cesariana (fls. 34/38).

Em seguida, a parte autora manifestou-se requerendo a inclusão do Hospital e Maternidade Marieta Konder Bornhausen no polo passivo da demanda (fls. 44/45), o que foi deferido (fl. 46). (Sentença em Processo n. 033.12.010197-4, Itajaí)

A antecipação de tutela foi deferida (págs. 24/27). Citado regularmente, o segundo requerido, Hospital Marieta Konder Bornhausen interpôs Agravo de Instrumento com efeito suspensivo à decisão atacada (págs. 45/57). (Sentença em Processo n. 0301858 -78.2015.8.24.0048, Balneário Piçarras)

O primeiro trecho informa que o Hospital não era réu desde o início da ação, mas fora apontado como tal pela autora em momento posterior por se recusar a realizar a laqueadura. Baseando-nos em tais indícios, podemos concluir que essa foi a mesma razão pela qual a autora do segundo processo citado tenha apontado o mesmo Hospital como réu, ainda que na decisão analisada não exista menção expressa a uma recusa por parte dele. No terceiro trecho, sabemos que o Hospital não atendeu à ordem judicial, pois interpôs recurso, no intuito de não 
realizar a incumbência. O que todos esses trechos nos dizem é que, mesmo quando há o deferimento de tutela antecipada por parte de um magistrado, não necessariamente significa que a ordem será cumprida, pois o Hospital resiste para realizar a cirurgia.

Além disso, quando há o deferimento do pedido ao fim do processo, o Hospital interpõe recursos de apelação. Porém, em todas essas apelações analisadas, ${ }^{\mathbf{2 2}}$ a objeção não era relativa à realização da laqueadura, mas à negação em primeira instância da justiça gratuita. Isso pode significar que a realização da cirurgia em si não é uma preocupação, pois mesmo quando deferida em sede de tutela antecipada, o Hospital se abstém da obrigação por meio de recursos e, em razão da urgência do pedido, a intervenção acaba sendo realizada por outro hospital. Um fato que corrobora nossa interpretação é de que, entre os anos de 2008 e 2012, nenhuma laqueadura foi realizada nesse hospital. ${ }^{23}$ As moradoras de Itajaí precisam, portanto, se dirigir à cidade de Penha para terem seu direito assegurado. ${ }^{24}$

Interessante destacar que em um dos casos, inclusive, o Hospital foi condenado por litigância de má-fé: 25

[...] não há que se falar em inexistência de litigância de má-fé, porque tanto na contestação quanto nas razões de apelação, o Hospital afirmou que não houve negativa para a realização do procedimento de laqueadura pleiteado pela autora. Todavia, como bem mencionado na decisão objurgada e no parecer do douto Procurador de Justiça, por mais que não haja nos autos documento que comprove a recusa do apelado em realizar o procedimento cirúrgico pleiteado na demanda, "afigura-se ilógico pensar que diversas mulheres gestantes - em sua grande maioria passando por dificuldades financeiras -, se deem ao trabalho de constituir advogado, arcarem com custas processuais e com

22 Votos disponíveis nos seguintes autos: Apelação Cível n. 2014.087804-2, de Itajaí; Apelação Cível n. 2014.015431-3, de Itajaí; Apelação Cível n. 2014.025298-7, de Balneário Piçarras; e Apelação Cível n. 2014.024864-1, de Itajaí.

23 Conforme notícia disponível no link: http://www.prb10.org.br/noticias/municipios/itajai-realizouapenas-30-laqueaduras-em-cinco-anos/. Acesso em: 28 mar. 2017.

24 Conforme notícia disponível no link: https://ricmais.com.br/sc/programas/rictv-itajai/hospital-deitajai-se-nega-a-fazer-laqueadura-e-vasectomia-por-questoes-religiosas. Acesso em: 28 mar. 2017.

25 Segundo a Lei n. 13.105/2015, Código de Processo Civil, art. 80. "Considera-se litigante de má-fé aquele que: I - deduzir pretensão ou defesa contra texto expresso de lei ou fato incontroverso; II - alterar a verdade dos fatos; III - usar do processo para conseguir objetivo ilegal; IV - opuser resistência injustificada ao andamento do processo; $\mathrm{V}$ - proceder de modo temerário em qualquer incidente ou ato do processo; VI provocar incidente manifestamente infundado; VII - interpuser recurso com intuito manifestamente protelatório". No caso, os magistrados entenderam que o Hospital deduziu defesa contra fato incontroverso (negativa de realização de laqueadura), e assim alterou a verdade dos fatos. 
as demais peculiaridades inerentes ao processo, objetivando apenas uma prestação jurisdicional inócua" (fl. 67). Além disso, conforme se observa à fl. 67, há uma série de demandas com a mesma causa de pedir (realização de laqueadura) ajuizadas contra o apelante em trâmite nesse Tribunal de Justiça, de forma que o argumento trazido aos autos pelo nosocômio, no sentido de que não há óbice para realização do procedimento aqui pleiteado, certamente não condiz com a realidade fática apresentada nos autos, uma vez que, diante do elevado número de ações com o mesmo objeto, é pouco crível que não haja "litigiosidade" na realização do procedimento de esterilização solicitado. Diante disso, restou claramente configurada a intenção do apelante em alterar a verdade dos fatos quando afirmou (tanto em contestação quanto nas razões de apelação) que não houve negativa de realização do procedimento pleiteado, o que vai inteiramente de encontro com fatos ocorridos nestes autos e em demais processos envolvendo o mesmo Hospital. Assim, aplicando-se as regras de experiência comum (art. 335 do CPC), após a análise dos fatos acima mencionados, resta claramente caracterizada a hipótese de litigância de má-fé prevista no inciso II do art. 17 do Código de Processo Civil. (Voto em Apelação Cível n. 2014.025298-7, Balneário Piçarras, grifo nosso)

Se nos ativermos ao fragmento acima transcrito, encontraremos um outro vestígio que auxilia nossa análise. Trata-se da menção do magistrado aos diversos casos similares que chegaram ao Tribunal de Justiça de Santa Catarina (TJSC), tendo a mesma instituição por ré. Se várias demandas sobre o tema têm chegado ao judiciário, podemos inferir que o direito ao planejamento familiar assegurado pela Constituição não está sendo efetivamente cumprido sem coerção estatal, encontrando diversos obstáculos pelo caminho.

Apesar de os casos analisados serem referentes apenas ao estado de Santa Catarina, acreditamos que o acesso à laqueadura no cenário nacional encontra obstáculos semelhantes: isto é, recusa por parte dos hospitais e profissionais de saúde por motivos diversos. Caetano (2014, p. 312-316) revisita pesquisas de 1999 a 2009, realizadas em cidades como São Paulo, Palmas, Recife, Belo Horizonte, Curitiba e Cuiabá, dentre outras regiões, concluindo que os próprios critérios legais:

[...] tendem a constituir-se como obstáculos à obtenção da laqueadura tubária no SUS por eventual oposição do parceiro, por desistência durante o período de espera, por dificuldade em iniciar o processo mais de um mês e meio após o nascimento da criança, por discordância do profissional com os critérios da lei e pela falta de serviço credenciado. (Grifo nosso)

A partir desses elementos podemos inferir que, apesar de regulamentada, a laqueadura feminina ainda encontra entraves de ordens diversas, que vão de aspectos religiosos às arbitrariedades por parte dos profissionais de saúde que exigem critérios extralegais, demonstrando 
uma flagrante resistência à efetivação dos direitos sexuais e reprodutivos e do próprio planejamento familiar.

Nesse sentido, é pertinente indagar como o Judiciário se porta em relação a essas resistências: quais seriam os argumentos utilizados para deferir a realização das laqueaduras? Por mais diversos que sejam os motivos para a não realização da laqueadura por parte de alguns hospitais, os critérios estabelecidos na Lei do Planejamento Familiar devem ser obedecidos, sendo sua inobservância um fundamento jurídico válido, pois se trata de uma lei vigente, promulgada em um contexto de esterilização em massa de mulheres brasileiras e de interferência estrangeira para o controle populacional do país. O que se observa, porém, é uma tendência a mitigar os dispositivos dessa norma. Mesmo com critérios e proibições legais, a maioria dos magistrados (19, dos 20 casos em análise) defere o pedido de realização de laqueadura: ${ }^{26}$

No mais, é sabido que a esterilização cirúrgica só pode ocorrer durante o parto nos casos de comprovada necessidade, por cesarianas sucessivas anteriores (art. $10, \S 2^{\circ}$ ). Seja como for, em que pese não tenha ficado claro, da leitura da inicial, se a autora já realizou outras cesarianas, é certo que submetê-la a novo procedimento cirúrgico para a pretendida esterilização implicaria novos riscos à sua saúde, os quais devem ser considerados. (Sentença no Processo n. 306880-31.2016.8.24.0033, Itajaí, grifo nosso)

Com relação ao requisito elencado no art. $10, \S 5^{\circ}$ da Lei $n .^{\circ} 9.263 / 96$, o qual remete a necessidade de consentimento expresso de ambos os cônjuges, estando os mesmos na vigência da sociedade conjugal, entendo que desnecessário, tendo em vista os fatos narrados na inicial, os quais demonstram a real necessidade da esterilização, inclusive por possuírem a autora e seu cônjuge parcos recursos, como bem demonstram os documentos de págs. 20/23. (Antecipação de Tutela em Processo n. 0301858-78.2015.8.24.0048, Balneário Piçarras, grifo nosso)

Nos trechos das duas decisões destacadas, há o abrandamento de algum requisito legal. $\mathrm{Na}$ primeira, a juíza admite que não restou explícita a submissão da autora a outras cesarianas o que é uma exceção à proibição de laqueadura imediata pós-parto -, mas que ainda assim irá

26 A única exceção se deu no Processo n. 0029503-89.2012.8.24.0038, de Joinville. Segundo o juiz Renato Roberge, nos autos "Não há qualquer prova que trouxesse a necessidade do procedimento concomitantemente ao parto cesáreo, isto é, da existência de risco à saúde da autora. Logo, inevitável o indeferimento do pedido, uma vez que em manifesta contrariedade ao comando legislativo que trata da questão, cumprindo gizar que não se infere tenha o demandado negado-se à realização do procedimento, mas apenas condicionado a esterilização após decurso do prazo de 45 dias do parto cesárea, que estabelecido em lei”. 
deferir o pedido para que o procedimento seja realizado. Na segunda, a juíza afasta o requisito de autorização expressa do cônjuge.

Observe-se, assim, que os magistrados tendem a emitir ordem judicial para que o procedimento seja efetivado mesmo quando da inobservância dos critérios legais, o que pode apontar para uma necessidade de se rediscutir a lei, que parece não atender a uma necessidade social. Alguns, utilizando-se da prerrogativa do controle difuso de constitucionalidade, entendem que a proibição da laqueadura imediata pós-parto é inconstitucional, motivo pelo qual não deve ser obstáculo para as partes interessadas:

Tal proibição, por assim dizer, da realização da laqueadura concomitantemente com o parto é de constitucionalidade questionável, notadamente perante o art. 226, § $7^{\circ}$ da Constituição Federal, que regra ser o planejamento familiar de livre decisão do casal. (Antecipação de Tutela em Processo n. 0300767-46.2016.8.24.0135, Navegantes, grifo nosso)

Assim, o assunto deve ser analisado sob a ótica dos princípios da proporcionalidade, da razoabilidade e da dignidade da pessoa humana, respeitando-se o direito à saúde e à vida, constitucionalmente resguardados. (Antecipação de Tutela em Processo n. 0307599 -13.2016.8.24.0033, Itajaí, grifo nosso)

Nos trechos das duas decisões, o direito constitucional é invocado como forma de atenuar as exigências e requisitos legais. A proibição da laqueadura imediatamente após o parto, porém, além de se basear na ideia de que a mulher se encontra em período de vulnerabilidade, encontra respaldo no fato de que antes da regulamentação desse tipo de cirurgia, diversas mulheres se submetiam a cesarianas desnecessariamente, o que parece não ter se modificado com a promulgação da lei, provavelmente em virtude de sua não observância. A Organização Mundial de Saúde atesta que em 2016 o Brasil era o segundo maior país com nascimentos via parto cesariano $(55,6 \%)$, perdendo apenas para a República Dominicana (56\%), enquanto a média mundial era de $18,6 \% .{ }^{27}$

Por fim, interessava-nos compreender o que motivava os juízes a afastarem as prerrogativas legais: seria a preocupação em efetivar um direito da mulher, preservando a autonomia de sua vontade e levando em consideração, ainda que remotamente, os quatro princípios basilares dos direitos reprodutivos, propostos por Corrêa e Petchesky (1996)?

Vejamos o que dizem as próprias decisões: explosao-de-cesareas, 70002190283. Acesso em: 14 jun. 2018. 
Assim, considerando as peculiaridades do caso concreto, em que a interessada, pessoa desprovida de maiores recursos financeiros, mãe solteira de 5 (cinco) filhos menores, grávida do $6^{\circ}$ (sexto) e beneficiária da assistência social, por não querer mais aumentar sua prole, busca o Poder Público, deve-se, sim, facilitar o seu acesso ao procedimento de esterilização voluntária e não embaraçá-lo. (Voto em Apelação Cível n. 2014.054880-2, Navegantes)

Com relação ao requisito elencado no art. $10, \S 5^{\circ}$ da Lei n. ${ }^{\circ} 9.263 / 96$, o qual remete a necessidade de consentimento expresso de ambos os cônjuges, estando os mesmos na vigência da sociedade conjugal, entendo que desnecessário, tendo em vista os fatos narrados na inicial, os quais demonstram a real necessidade da esterilização, inclusive por possuírem a autora e seu cônjuge parcos recursos, como bem demonstram os documentos de págs. 20/23. (Antecipação de Tutela em Processo n. 0301858-78.2015.8.24.0048, Balneário Piçarras)

Percebe-se, no primeiro trecho, que até há uma menção ao desejo da requerente. Todavia, a motivação de ambos contém elementos para se pensar que a atenuação dos critérios legais por parte do próprio Poder Judiciário apresenta resquícios, talvez inconscientes, de uma visão controlista. A mulher tem o direito à laqueadura, mas não porque é sua vontade, ou porque o hospital agiu arbitrariamente: em 6 dos 20 casos analisados, um dos principais argumentos é a hipossuficiência financeira da mulher ou do casal, e a existência de outros filhos. Esse pensamento é compreensível, uma vez que filhos geram despesas financeiras, mas deve ser visto com cautela para não ultrapassar a autonomia da vontade feminina e as condições de seu poder de escolha. Por essas razões, entendemos que tais fundamentos podem ser interpretados como indícios de um pensamento controlista, segundo o qual a alta taxa de natalidade está diretamente ligada à hipossuficiência financeira.

Nesse sentido, um dos casos mais recentes ocorridos no país é o de Janaína Aparecida Quirino, uma morada de rua e dependente química cuja esterilização compulsória foi solicitada judicialmente ao município de Mococa (SP) pelo Ministério Público mediante Ação Civil Pública. Sem adentrar no mérito do consentimento da mulher para realização da cirurgia (que, segundo o Tribunal de Justiça de São Paulo, não restou comprovado em razão de suas resistências), são preocupantes os termos do pedido do Ministério Público para seu cumprimento, deferido liminarmente:

Compulsando os autos, verifico que, de acordo com o Departamento de Saúde do Município, Janaína não compareceu voluntariamente à consulta ginecológica agendada (fls. 44/46). Ora, em se tratando de ação que visa à realização de cirurgia de esterilização compulsória, a resistência da requerida era esperada, motivo pelo qual foi pleiteado pelo Ministério Público e determinada liminarmente a realização de cirurgia de laqueadura, 
a qual deve ser feita mesmo contra a vontade da requerida. Caso contrário, nem seria necessário o ajuizamento de ação judicial. (BRASIL, 2017, p. 50, grifo nosso)

Ou seja, a partir do argumento da hipossuficiência financeira e da situação precária em que sua vida se encontra, a vontade da mulher deve ser ignorada para que os impactos socioeconômicos de uma nova gravidez não sejam suportados pelo Estado. Não há, nos autos, menção a sugestão de métodos contraceptivos mais duradouros, como o Dispositivo Intrauterino (DIU) cuja duração pode chegar a 10 anos e é um método reversível. Também não há preocupação em verificar o contexto no qual a suposta vontade da mulher foi emitida: se ela gozava de discernimento (Lei n. 9.263/1996, art. 10, $\S 3^{\circ}$ ), se sua capacidade civil não estaria comprometida em razão do uso de drogas (Código Civil, art. $4^{\circ}$, inc. II) e o que ela própria teria a dizer (já que o processo foi julgado antecipadamente, sem realização de audiência, e ela não contou com a assistência de nenhum tipo de defesa jurídica).

Assim, se, por um lado, os hospitais e profissionais da saúde estabelecem variados critérios extralegais para negar os pedidos de laqueadura, desconsiderando a vontade da mulher, por outro, o Judiciário abranda os requisitos estabelecidos em lei, reproduzindo, ainda que inconscientemente, um viés controlista segundo o qual a esterilização feminina é um caminho natural a ser seguido, porque diminui de modo eficaz a taxa de natalidade propiciando melhora nas condições sociais e financeiras dessas mulheres. Não é observado, por exemplo, se outros métodos menos invasivos lhes foram oferecidos, se sua vontade é manifestada de maneira consciente (se ela conhece os riscos da cirurgia, os efeitos colaterais, se não há algum tipo de pressão para seu consentimento) ou se os prazos e garantias legais, que não foram pensados ao acaso, serão obedecidos.

De fato, tem-se que o último elemento a ser observado quando se trata do deferimento judicial para a realização da cirurgia é a autonomia da vontade feminina, quais são as condições de manifestação desse desejo e a efetiva consciência sobre o que se solicita.

\section{CONSIDERAÇÕES FINAIS}

Partindo de uma preocupação relativa à efetivação dos direitos reprodutivos das mulheres brasileiras, procurou-se, a partir de uma pesquisa documental, identificar como os magistrados decidem os casos relativos à laqueadura, nas situações em que há algum tipo de recusa por parte dos hospitais.

A partir da análise de decisões proferidas em 20 casos, emitidas nos anos de 2015 e 2016, foi possível concluir que dentro desse recorte espacial e temporal a Lei do Planejamento Familiar não possui eficácia real, visto que algumas das cautelas tomadas pelo legislativo na época de promulgação da lei (como a impossibilidade de realização de laqueadura no momento do parto) são mitigadas tanto pelos profissionais de saúde quanto pelos juízes. Ainda que estes últimos possuam a prerrogativa do controle difuso de constitucionalidade, elementos da lei que visavam à proteção da mulher contra atitudes arbitrárias também podem ser ignorados, como 
a realização de laqueadura sem a democratização do conhecimento necessário sobre o método (sua irreversibilidade e a existência de métodos menos invasivos, por exemplo).

Estamos cientes da limitação de nosso método e de nosso resultado, que abrange apenas um estado da Federação em um curto período. No entanto, a partir de leituras de outras pesquisas realizadas em outras localidades, como indica a revisão bibliográfica de Caetano (2014, p. 312-316), que abrange os anos de 1999 a 2009 e cidades como São Paulo, Palmas, Recife, Belo Horizonte, Curitiba e Cuiabá, é possível sustentar a hipótese passível de teste, de que a ineficácia da Lei do Planejamento Familiar não é uma realidade local. Nesse sentido, compreendemos que o afã de auxiliar a efetivação dos direitos reprodutivos femininos pode ser influenciado, ainda que inconscientemente, por pensamentos controlistas que, na prática, não têm por preocupação central as condições nas quais a mulher realizará a cirurgia de esterilização voluntária: se há ciência da possibilidade de uso de outros métodos, se os efeitos colaterais lhe foram explicados, se haverá apoio de equipe multidisciplinar, se o parto via cesárea é realmente a melhor opção para cada caso ou se será feito no intuito de facilitar o acesso à laqueadura, dentre diversos outros fatores.

Assim, entendemos que é necessária uma revisão das políticas públicas de acesso à laqueadura, seja rediscutindo a lei em vigor, seja apostando na educação dos agentes institucionais sobre a importância de se respeitar a autonomia feminina a partir de um viés amplo, que compreenda a manifestação da vontade de uma forma contextualizada. As condições de decisão de uma mulher branca de classe média não são as mesmas de uma mulher negra moradora de rua. É preciso, portanto, garantir que haja instrução a respeito da laqueadura, seus riscos, seus efeitos colaterais, a possibilidade de uso de outros métodos menos invasivos e tão eficazes quanto.

O que é certo, porém, é que, apesar de toda a luta para regulamentação do procedimento nos anos 1990, visando coibir uma política de controle populacional vigente no Brasil, a Lei do Planejamento Familiar aparece como letra morta, suprimida e reinterpretada a partir de argumentos que soam como aqueles defendidos por um viés controlista, ainda que de modo não intencional.

\section{AGRADECIMENTOS}

Os autores agradecem ao Ministério da Ciência, Tecnologia e Inovação (MCTI) / Conselho Nacional de Desenvolvimento Científico e Tecnológico (CNPq) e à Coordenação de Aperfeiçoamento de Pessoal de Nível Superior (CAPES). 


\section{REFERÊNCIAS}

ALVES, José Eustáquio Diniz. As políticas populacionais e o planejamento familiar na América Latina e no Brasil. Rio de Janeiro: Escola Nacional de Ciências Estatísticas, 2006.

ALVES, José Eustáquio Dinis; CORRÊA, Sonia. Demografia e ideologia: trajetos históricos e os desafios do Cairo + 10. Revista Brasileira de Estudos de População, v. 20, n. 2, jul./ dez. 2003.

BRASIL. Antecipação de Tutela em Processo n. 0307599-13.2016.8.24.0033 - de Itajaí. Ana Paula Terezinha Souza da Silva e Unimed Porto Alegre - Cooperativa Médica Ltda. Juíza: Ana Vera Sganzerla Truccolo.

BRASIL. Antecipação de Tutela em Processo Ordinário n. 0300767-46.2016.8.24.0135 - de Navegantes. Elisangela Linhares e UNIMED Litoral. Juiz: Murilo Leirião Consalter.

BRASIL. Apelação Cível em Mandado de Segurança n. 2014.068404-3 - de Araranguá. Ministério Público do Estado de Santa Catarina e Município de Araranguá. Relator: Ricardo Roesler.

BRASIL. Congresso Nacional. Exame da incidência da esterilização em massa de mulheres no Brasil. Brasília: Comissão Parlamentar de Inquérito, 1993. Disponível em: http://www2.senado.leg.br/bdsf/bitstream/ handle/id/85082 /CPMIEsterilizacao.pdf?sequence=7. Acesso em: 14 jun. 2018.

BRASIL. Despacho no Processo Ordinário n. 0307599-13.2016.8.24.0033 - de Itajaí. Ana Paula Terezinha Souza da Silva e Unimed Porto Alegre. Juíza Ana Vera Sganzerla Truccolo. 24 de agosto de 2016.

BRASIL. Dossiê de tramitação do Projeto de Lei n. 209/1991. Brasília: Congresso Nacional, 1995. Disponível em: https: / /goo.gl/Q3eE7Z. Acesso em: 14 jun. 2018.

BRASIL. Lei n. 9.263. Lei do Planejamento Familiar. 12 de janeiro de 1996.

BRASIL. Lei n. 13.105. Código de Processo Civil. 16 de março de 2015.

BRASIL. Ministério da Saúde. Portaria n. 48, de 11 de fevereiro de 1999. Diário Oficial da União, 17 fev. 1999.

BRASIL. Poder Executivo. Decreto-Lei n. 7.967. 18 de setembro de 1945. Disponível em: http://www2. camara.leg.br/legin/fed/declei/1940-1949/decreto-lei-7967-18-setembro-1945-416614-publicacaooriginal1-pe.html. Acesso em: 14 jun. 2018. 
BRASIL. Sentença em Ação Civil Pública n. 0000899-50.2014.8.24.0135. Ministério Público do Estado de Santa Catarina e Estado de Santa Catarina. Juiz: Murilo Leirião Consalter.

BRASIL. Sentença em Processo Ordinário n. 0007969-41.2011.8.24.0033 - de Itajaí. Paula Regina Maximo da Silva dos Santos e Hospital e Maternidade Marieta Konder Bornhausen. Juíza: Francielli Stadtlober Borges Agacci.

BRASIL. Sentença em Processo Ordinário n. 033.12.010197-4 - de Itajaí. Anna Karina Amado Kluser e Hospital e Maternidade Marieta Konder Bornhausen. Juiz: Carlos Roberto da Silva.

BRASIL. Sentença em Processo Ordinário n. 306880-31.2016.8.24.0033 - de Itajaí. Samanta Cristina Rosa Sebastião e Hospital e Maternidade Marieta Konder Bornhausen. Juíza: Francielli Stadtlober Borges Agacci.

BRASIL. Sentença em Processo Ordinário n. 0029503-89.2012.8.24.0038 - de Joinville. Rosimeri Cardoso e Estado de Santa Catarina. Juiz: Renato Roberge.

BRASIL. Tribunal de Justiça de Santa Catarina. Antecipação de Tutela em Processo Ordinário n. 0301858 78.2015.8.24.0048 - de Balneário Piçarras. Gabriela DuarteVicente e Município de Penha. Juíza: Regina Aparecida Soares Ferreira.

BRASIL. Tribunal de Justiça de São Paulo. Ação Civil Pública n. 1001521-57.2017.8.26.0360 - de Mococa. Ministério Público de São Paulo, Janaína Aparecida Quirino e outro. Juiz: Djalma Moreira Gomes Júnior. 31 de maio de 2017. Disponível em: https: / / drive.google.com/file/d/1INTfDLL9zGVgsTHu2QoMcRd6laX dGNlU/view?usp=sharing. Acesso em: 14 jun. 2018.

BRASIL. Voto em Agravo de Instrumento n. 0156766-19.2015.8.24.0000 - de Balneário Piçarras. Instituto das Pequenas Missionárias de Maria Imaculada - Hospital e Maternidade Marieta Konder Bornhausen, Leia Damaris Olinek de Lima e Município de Penha. Relator: João Henrique Blasi.

BRASIL. Voto em Apelação Cível n. 2014.054880-2 - de Navegantes. Estado de Santa Catarina e Ministério Público de Santa Catarina. Relator: Edemar Gruber.

BRASIL. Voto em Apelação Cível n. 2014.043265-7 - de Navegantes. Estado de Santa Catarina, Janaína Rodrigues, Município de Navegantes. Relator: Cid Goulart.

BRASIL. Voto em Apelação Cível n. 2014.025298-7 - de Balneário Piçarras. Fundação Hospitalar de Santa Catarina Hospital e Maternidade Marieta Konder Bornhausen e Neusa Maria Cardoso. Relator: Pedro Manoel Abreu. 22 de outubro de 2015. 
CAETANO, André Junqueira. Esterilização cirúrgica feminina no Brasil, 2000 a 2006: aderência à lei de planejamento familiar e demanda frustrada. Revista Brasileira de Estudos Populacionais, Rio de Janeiro, v. 31, n. 2, p. 309-331, 2014.

CARVALHO, Luiz de; OSIS, Maria José Duarte; CECATTI, José Guilherme; BENTO, Silvana Ferreira; MANFRINATI, Márcia B. Esterilização cirúrgica voluntária na Região Metropolitana de Campinas, São Paulo, Brasil, antes e após sua regulamentação. Caderno de Saúde Pública, Rio de Janeiro, v. 23, n. 12, p. 2906-2916, 2007.

CATECISMO DA IGREJA CATÓLICA. São Paulo: Loyola, 2000.

CATECISMO DA IGREJA CATÓLICA. Itens 2297 e 2399. Disponível em: http://www.vatican. va/archive/cathechism_po/index_new/p3s2cap2_2196-2557_po.html. Acesso em: 2 abr. 2019.

CRETElla JúniOR, José. Valor Jurídico da Portaria. Revista de Direito Administrativo, Rio de Janeiro, n. 117 , p. 447-459, 1974.

CORRÊA, Sonia; ALVES, José Eustáquio Diniz; JANNUZZI, Paulo de Martino. Direitos e saúde sexual e reprodutiva: marco teórico-conceitual e sistema de indicadores. In: CAVENAGHI, Suzana (coord.). Indicadores municipais de saúde sexual e reprodutiva. Rio de Janeiro: ABEP, 2006. p. 14-26.

CORRÊA, Sonia; PETCHESKY, Rosalind. Direitos sexuais e reprodutivos: uma perspectiva feminista. Physis, v. 6, n. 1-2, p. 147-177, 1996.

FREEDMAN, Lynn P.; ISAACS, Stephen L. Human rights and reproductive choice. Studies in Family Planning, v. 24, n. 1, p. 18-30, 1993.

GALETTI, Camila Carolina Hildebrand. Corpo e feminismo: a marcha das vadias de Campinas/SP. 2016. 105 f. Dissertação (Mestrado em Sociologia) - Instituto de Ciências Sociais, Universidade de Brasília, UnB, 2016.

MAGAlHÃES, Adriana Cristina de; PEREIRA, Daliane da Silva Alves; JARDIM, Danúbia Mariane Barbosa; CAILlAUX, Michele; SALES, Vinícius Bernardo Lemos. Vivência da mulher na escolha do Método de Ovulação Billings. Revista Brasileira de Enfermagem, Brasília, v. 66, n. 4, p. 485-492, 2013.

MATTAR, Laura Davis. Reconhecimento jurídico dos direitos sexuais: uma análise comparativa com os direitos reprodutivos. Revista Internacional de Direitos Humanos, v. 5, n. 8, p. 60-83, 2008.

PAULO VI. Carta Encíclica Humanae Vitae, sobre a regulação da natalidade, n. 14. 
PIO XII. Alocução ao Congresso da União Católica Italiana das Parteiras, 29 de outubro de 1951, em AAS 43 (1951), p. 835-854.

PIO XII, Alocução aos Participantes do Congresso de Associação Italiana de Urologia, de 8 de outubro de 1953.

OSIS, Maria José Duarte; CARVALHO, Luiz Eduardo Campos de; CECATTI, José Guilherme; BENTOL, Silvana Ferreira; PÁDUA, Karla Simônia de. Atendimento à demanda pela esterilização cirúrgica na Região Metropolitana de Campinas, São Paulo, Brasil: percepção de gestores e profissionais dos serviços públicos de saúde. Cadernos de Saúde Pública, Rio de Janeiro, v. 25, n. 3, p. 625-634, mar. 2009. Disponível em: http: / / www.scielo.br/scielo.php?script=sci_arttext\&pid=S0102-311X2009000300017\&lng =en\&nrm=iso. Acesso em: 22 fev. 2019.

ROSENFELD, Michel. Deconstruction and legal interpretation: conflict, indeterminacy and the temptations of the new legal formalism. In: CORNELL, Drucila; ROSENFELD, Michel; CARLSON, David Gray. Deconstruction and the possibility of justice. Nova York: Routledge, 1992.

SAGRADA CONGREGAÇÃO PARA A DOUTRINA DA FÉ. Resposta sobre a esterilização nos hospitais católicos, Quaecumque sterilizatio. AAS, 68 (1976), 13 de março de 1975.

\section{COMO CITAR ESTE ARTIGO:}

OLIVEIRA, Amanda Muniz; RODRIGUES, Horácio Wanderlei. Blessed be the fruit: resquícios de um viés controlista em ações sobre cirurgia de laqueadura no Judiciário de Santa Catarina (20152016). Revista Direito GV, v. 15, n. 1, jan./abr. 2019, e1906. doi: http://dx.doi.org/10.1590/23176172201906.
Amanda Muniz Oliveira

Doutora e Mestra em Direito pelo Programa de Pós-Graduação em Direito (PPGD) da Universidade Federal de Santa Catarina (UFSC). Pesquisadora do Núcleo de Estudos CONHECER DIREITO - NECODI (IMED/UFSC/CNPQ) E DO LILITH Núcleo de Pesquisa em DiReito e Feminismos (UFSC/CNPQ).

amandai04019gmail.com

\section{Horácio Wanderlei Rodrigues}

Doutor e Mestre em Direito pelo Programa de Pós-Graduação em DiReito (PPGD) da Universidade Federal de

SANTA CATARINA (UFSC). EstágIOS DE PÓS-DOUTORADO EM FILOSOFIA/PPGFIL/UNISINOS E EM EDUCAC̦ÃO/FACED/UFRGS. Professor Permanente do PPG Direito/IMED/RS. Sócio-FUNDADOR dO CONPEDI E dA ABEDI. MEMBRO DO INSTITUTO

Iberomericano de Derecho Procesal. Coordenador e

Pesquisador do Núcleo de Estudos Conhecer DiReito NECODI (IMED/UFSC/CNPQ). PESQUISADOR DO CNPQ.

horaciowragmail.com 